\section{Robert Wallace Glass}

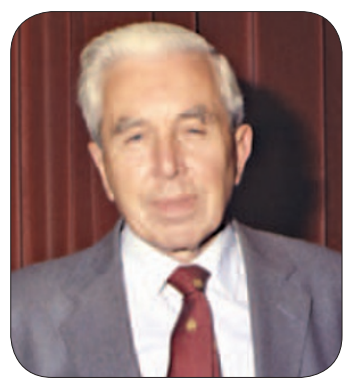

Robert Wallace Glass was born on the Isle of Arran on 21 March 1927. His family later moved to Perth where Wallace attended Perth Academy before studying dentistry at Dundee. In 1948 he served as a House Officer in Dundee Dental Hospital, until his call-up to the RAF where he served as a Dental Officer for two years.

On his discharge, Wallace joined Dr Sydney McPherson in dental practice in Union Street, Dundee. After Dr McPherson's retiral Wallace looked after the dental needs of his largely NHS patients singlehandedly until his own retiral in 1992.

Wallace was a loyal, hard-working member of the BDA; he was the Dundee delegate to the BDSA Conference in 1946-7 and served as President of the North of Scotland Branch in 1978-9.

In 1975 the North of Scotland Branch elected him to the Representative Board and he was a member for 15 years. He was a member of the Scottish General Dental Services Committee, initially as Branch Representative and latterly as a member of the General Dental Services Committee elected from the Representative Board.

As Chairman of SGDSC (1985-1991), he took on the unenviable task of being part of the team negotiating a new GDS Contract; the end result was unpopular with dentists in Scotland, even though Wallace did manage to modify the original proposals to make the package better suited to Scottish dental disease patterns. Wal-

\section{John F. Bates}

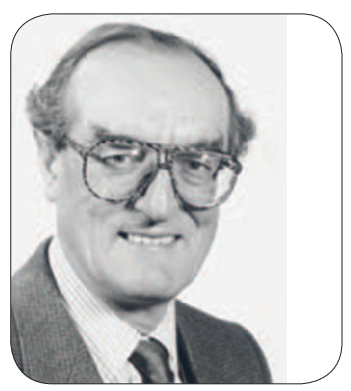

John Bates died in hospital in Cardiff on 23 March 2007 aged 82 after a long illness. Born in Carlton, Nottingham, John was educated at Nottingham Higher Pavement School, but left at 16 to work for an insurance company. He served in the Fleet Air Arm from 1943-6 with the Home Fleet protecting Russian convoys, and after cessation of hostilities continued to serve in Ceylon and India. After the war he took an ex-service grant and went to Newcastle to read dentistry at the Sutherland Dental School, and graduated BDS (Hons) in 1953. He married Nancy in 1952 after meeting her at a nurses' dance, and so began a long and happy partnership that supported him throughout the next 56 years.

After a short time in general practice, and as a house surgeon in the dental hospital in Newcastle, he moved to the Department of Prosthetics at the Turner Dental School in Manchester in 1954. He was appointed Senior Lecturer and Head of the Division of Prosthetic Dentistry in Cardiff in 1964, and later Professor of Restorative Dentistry.

\section{He was a good and faithful servant to the profession...}

lace was disappointed by the reaction of many of the profession, although few doubted his integrity and the undoubted efforts he had made to achieve a better situation for his colleagues and patients.

His exemplary life of service to his profession was recognised with the award of MBE in 1987. In 2001 his colleagues in the North of Scotland Branch also recognised his service to the BDA by nominating him for Life Membership.

After he retired Wallace pursued his interest in classical music, the theatre and walking the hills and dales. His interest in classical music was such that he gained an Open University BA degree with Honours, majoring in Music. The last time I saw him was at Pitlochry Theatre where he and Vera were enjoying one of their frequent visits to the Theatre in the Hills.

Wallace was always willing to take on any challenge and was at the same time an interesting and convivial companion. He will be sadly missed by all but particularly by Vera, his wife of many years, his son Kenneth, daughter Linda and their families.

Wallace became unwell shortly before last Christmas. He passed away peacefully on 19 February 2007. He was a devoted family man, a good and faithful servant to the profession he graced for so many years and a caring professional to his many patients.

Alastair I. MacLean

\section{He was regarded with affection by} generations of students...

His CV is very long and impressive, and his work in Cardiff and Wales involved a huge amount of effort on numerous committees, commissions, councils, groups, associations and societies the UK and abroad.

He was truly 'wet fingered' and enjoyed all matters clinical. He was a dedicated teacher, both clinically and academically, and was in high demand as an examiner, adviser and assessor for Chairs and appointments both in the UK and overseas.

He was a firm but kindly teacher and although many students were greatly in awe of him he was easily approachable, and took a great interest in students and their future welfare. He was a very private man, with a dry sense of humour, and regarded with affection by generations of students at Manchester and Cardiff.

Our deepest sympathy is extended to Nancy and his daughters Anne and Judith and their families. 